\title{
"FAÇA-SE NA TERRA UM PEDAÇO DO CÉU": PERSPECTIVAS MESSIÂNICAS NA PARTICIPAÇÃO DOS PENTECOSTAIS NA POLÍTICA BRASILEIRA
}

\author{
"Build a Piece of Heaven on Earth": Messianic Perspectives on the \\ Pentecostals' Participation in Brazilian Politics
}

Daniel Rocha *

RESUMO: Este artigo analisa as relações entre crenças escatológicas e práticas políticas no pentecostalismo brasileiro e procura demonstrar a presença de elementos messiânicos nos discursos das lideranças pentecostais brasileiras. $\mathrm{O}$ texto tem como ponto de partida um encontro entre onze líderes pentecostais brasileiros com o presidente da república, Jair Messias Bolsonaro, em 05 de junho de 2020. O evento foi noticiado pela mídia e transmitido ao vivo. Analisamos, ao longo do texto, diversas falas e orações realizadas naquele evento e procuramos demonstrar como elas transmitiam uma autoconsciência messiânica daqueles líderes pentecostais. No desenvolvimento do texto, procuramos apresentar as transformações ocorridas nas relações entre crenças escatológicas e práticas políticas no pentecostalismo brasileiro e como tais transformações devem ser compreendidas à luz dos fatores teológicos, políticos e sociais que afetaram os pentecostais no Brasil.

PALAVRAS-CHAVE: Messianismo. Milenarismo. Pentecostalismo. Política e religião.

ABSTRACT: This article analyses the relationship between eschatological beliefs and political practices in Brazilian Pentecostalism. It also seeks to demonstrate the presence of messianic elements in the discourses of Brazilian Pentecostal leaders. The starting point of the article is a meeting between eleven Brazilian Pentecostal leaders and the Brazilian president, Jair Messias Bolsonaro, on June 5, 2020. The event was reported by the media and broadcast live. Throughout the text, we analysed

* Pontifícia Universidade Católica de Minas Gerais, Belo Horizonte, Minas Gerais, Brasil. 
several speeches and prayers made during the meeting and tried to demonstrate how they conveyed those Pentecostal leaders' messianic self-consciousness. We also sought to explore the transformations that took place in the relations between eschatological beliefs and the political practices of Brazilian Pentecostalism and how such transformations must be understood in the light of the theological, political and social factors that have affected Pentecostals in Brazil.

KEYWORDS: Messianism. Millennialism. Pentecostalism. Politics and Religion.

\section{Introdução}

B rasília, 05 de junho de 2020. No canal do Youtube do conhecido pastor Silas Malafaia foi transmitido, ao vivo, um ato de intercessão pelo Brasil e pelo presidente da República, ${ }^{1}$ no qual onze lideranças religiosas de algumas das principais igrejas pentecostais e neopentecostais brasileiras $^{2}$ na presença do presidente Jair Messias Bolsonaro, fizeram uma série de orações e "declarações proféticas" sobre seus governantes e sobre o futuro da nação. Em meio à enorme crise sanitária gerada pela pandemia da Covid 19 e, também, no turbilhão de uma série de polêmicas e conflitos institucionais no campo político, ${ }^{3}$ as falas dos pastores anunciavam a iminência de um futuro radiante para o país, enalteciam o papel fundamental a ser desempenhado por Bolsonaro no advento dessa nova era e reafirmavam a dimensão profética representada por aquele ato na sede do Poder Executivo nacional.

O apóstolo Renê Terra Nova, do Ministério Internacional da Restauração, afirmou que estavam ali "orando e profetizando e acreditando que o Brasil vai entrar na maior fase da sua história". No mesmo espírito, o bispo J.B. Carvalho, da Comunidade das Nações, também indicava "que o futuro é melhor do que o passado. Os nossos melhores dias estão à nossa frente. $\mathrm{O}$ Brasil vai brilhar pro mundo". Malafaia, com o tom incisivo e polêmico que lhe é peculiar, ressaltava o papel do "povo de Deus" e de suas lideranças ali representadas para esse momento de "virada" na história do Brasil:

Existem milhões de brasileiros orando por esse país. Esse país não vai ser Venezuela. Esse país não vai ser destruído por ninguém. Esse país não vai

\footnotetext{
${ }^{1}$ Vídeo disponível em: <https://www.youtube.com/watch?v=Fhn9-bLRxi0>. Acesso em: 15 jun. 2020.

${ }^{2}$ Abe Huber (Paz Church), Abner Ferreira (Assembleia de Deus em Madureira), César Augusto (Fonte da Vida), Eduardo Bravo (Universal do Reino de Deus), Estevam Hernandes (Renascer em Cristo), JB Carvalho (Comunidade das Nações), Renê Terra Nova (Ministério Internacional da Restauração), Rinaldo (Rina) Seixas (Bola de Neve), RR Soares (Internacional da Graça de Deus), Silas Malafaia (Assembleia de Deus Vitória em Cristo) e Victor Hugo (Vida Nova). ${ }^{3}$ Poucos dias antes, o ministro Alexandre de Moraes do Supremo Tribunal Federal havia determinado a investigação de uma série de pessoas próximas ao presidente no chamado inquérito das Fake News. Bolsonaro e seu apoiadores criticaram duramente o Supremo Tribunal Federal.
} 
falir [...]. Eu declaro, na autoridade do nome de Jesus, que vêm tempos de paz e de prosperidade. Que vêm tempos melhores [...]. Nós temos o poder da oração. E vão cair por terra toda essa potestade do inferno, esse principado pensando que vai destruir o país, convulsão institucional, convulsão social... Nós declaramos em nome de Jesus a paz sobre a nossa nação. E que vai vim [sic] dias de bênção. Eu creio. Eu creio. Eu não me assusto com o momento. Eu não me impressiono com circunstância. Eu não me impressiono com o momento que estamos vivendo.

Alguns dos líderes que se dirigiram diretamente ao presidente da República durante o ato fizeram a leitura de passagens bíblicas. Se Romanos 13, como esperado, foi recitado algumas vezes (Abe Huber e Abner Ferreira o evocaram em suas intervenções), destacaram-se nas falas e orações dos líderes ali presentes textos do livro de Isaías de caráter fortemente messiânico. Abe Huber citou Isaías 54 e disse a Bolsonaro que: “Nenhuma arma forjada contra você - porque a sua fé está em Cristo - [...] prosperará. E você condenará toda língua que quiser acusá-lo em juízo". Renê Terra Nova iniciou sua oração pelo presidente recitando Isaías 11: "Assim diz a Palavra do Senhor: e repousará sobre ele o espírito de sabedoria, o espírito de inteligência, o espírito de conselho e o espírito de fortaleza, o espírito de conhecimento e de temor do Senhor". O Apóstolo Rina da Igreja Bola de Neve afirmou que Deus lhe havia dado um texto muito específico (Is 41) e, voltando-se para Bolsonaro, disse que Deus

pediu para te dizer assim: Porém tu, servo meu, a quem elegi, meu amigo; Tu a quem tomei desde os confins da terra - lá no Vale do Ribeira [referindo-se à origem de Bolsonaro] - e te chamei de entre os seus mais excelentes e te disse: Tu és meu servo, te escolhi e nunca te rejeitei. Não temas porque eu sou contigo. Não te assombres porque eu sou teu Deus. Eu te fortaleço. Eu te ajudo. E te sustento com a destra da minha justiça. Eis que envergonhados e confundidos serão todos os que se indignaram contra ti. Tornar-se-ão em nada e os que contenderem contigo perecerão [...].

Sob o impacto dos elementos discursivos presentes naquele vídeo de aproximadamente meia hora, resolvi revisar um pouco da literatura sobre o messianismo nas ciências sociais. Poderíamos falar de um "novo messianismo" pentecostal? Inicialmente, se faz necessário deixar claro o que se entende como messianismo. A ideia de messianismo surgiu no contexto judaico, berço da concepção do messias. Segundo Queiroz (1976, p. 26), “o messias é o personagem concebido como um guia divino que deve levar o povo eleito ao desenlace natural do desenrolar da história, isto é, à humilhação dos inimigos e ao restabelecimento de um reino terreno e glorioso para Israel". A implantação de tal reino restaurador marcaria o "fim dos tempos".

No caso brasileiro, desde que entramos em contato com os livros didáticos de História na escola, a menção de messianismos e/ou milenarismos nos remete, quase que automaticamente, a movimentos - marcadamente 
rústicos - do início do século $X X$, que eram compostos por pessoas que vivenciavam contextos de crise social e de opressão por parte dos poderes estabelecidos (tanto o Estado quanto a Igreja oficial). Tais movimentos eram "interpretados, na ótica oficial, como arcaísmos deletérios e antiprogressistas, quando não como episódios de loucura coletiva, a que se chega a partir de efeitos desencadeadores da loucura do líder" (NEGRÃO, 2001, p. 120). Neles, a esperança da chegada de um tempo futuro de paz e justiça estaria sempre presente. "Outros movimentos religiosos e sociais de reação a crises podem existir, mas só serão messiânicos os que tratarem da instalação do Milênio por um enviado divino" (QUEIROZ, 1976, p. 352).

Entretanto, é preciso ampliar o horizonte conceitual e analítico sobre tais movimentos para que não nos limitemos a fazer um mero exercício comparativo com movimentos tradicionalmente definidos como messiânicos, como Canudos, Contestado e, em parte, Juazeiro. O messianismo, como o próprio nome diz, está ligado à figura de um messias que "é o personagem cujo movimento é o milenarismo, embora não haja necessariamente personagem e movimento" (DESROCHE, 1985, p. 54). Uma diferenciação mais clara entre os dois conceitos demandaria um trabalho bem mais amplo e completo, mas, de maneira geral, pode-se dizer que "o problema do Milênio é mais vasto do que o problema do messianismo" (QUEIROZ, 1976, p. 31). Pode existir Milênio sem a presença do enviado divino, mas não existe messias que não aponte para os mil anos de felicidade. Além disso, o papel messiânico pode não ser desempenhado por um indivíduo específico, mas sim por uma comunidade ou mesmo um "povo messiânico". ${ }^{4}$

\section{Pentecostalismo e escatologia}

É bem conhecida a história do surgimento do "pentecostalismo moderno" nos Estados Unidos do início do século XX. Se nas acaloradas pregações dos períodos dos avivamentos do século XIX já se presenciavam várias experiências de êxtase religioso - choros, gritos, danças etc. - como expressão de um contato direto com Deus, o pentecostalismo levou tais experiências a uma outra dimensão. Para eles, Deus estaria proporcionando aos crentes uma "bênção especial" como a que marcou a igreja primitiva, sendo os relatos do Dia de Pentecostes apresentados não mais como um evento

\footnotetext{
${ }^{4} \mathrm{O}$ caso dos Estados Unidos como uma espécie de "nação redentora" (MOLTMANN, 2003, p. 188) é um importante exemplo dessa perspectiva. Dizia Hermman Melville em um trecho do romance White Jacket (1850): "Nós, americanos, somos um povo peculiar, escolhido - o Israel do nosso tempo. Carregamos às costas a arca das liberdades do mundo [...]. Deus predestinou a nossa raça, e a humanidade espera grandes feitos dela. E nobres sentimentos trazemos dentro do peito. Logo as outras nações estarão na nossa esteira [...]. Demasiado tempo duvidamos de nós mesmos e nos perguntamos se o Messias político de fato viera. Mas ele veio em nós (MELVILLE, 2011, p. 200-201, tradução nossa)".
} 
único ligado ao período apostólico, mas como uma experiência acessível ao homem moderno através da fé. No início do século XX, Charles Fox Parham pregava e ensinava sobre o batismo no Espírito Santo, que teria no dom da glossolalia sua manifestação por excelência, e William J. Seymour deu grande visibilidade ao novo pentecostalismo nos cultos da Rua Azusa em Los Angeles.

O pentecostalismo inicial caracterizava-se por uma rejeição ao intelectualismo teológico e pelos cultos pouco formais e mais emocionais, destacando-se as manifestações de glossolalia, a oralidade e as experiências de cura divina. O pentecostalismo atraiu um público - composto principalmente por negros e imigrantes - que se sentia excluído do intelectualizado protestantismo tradicional. E, embora tenha tido alguma presença no sul agrícola e em outras regiões mais pobres dos EUA posteriormente, a explosão do pentecostalismo se deu entre as camadas mais desfavorecidas dos grandes centros urbanos que surgiam, como Los Angeles e Chicago, por exemplo. Entre seus atrativos para tal público, podemos elencar a já citada aversão ao preparo teológico e ao intelectualismo entre suas lideranças, a maior abertura para a participação de mulheres na liderança das comunidades e a criação de um espaço não segregacionista, em um país onde negros e imigrantes sofriam forte discriminação.

A questão escatológica logo se destacou entre os pentecostais. A "nova descida" do Espírito Santo seria um sinal da aproximação do fim dos tempos. Esse novo despertar conferia aos pentecostais um lugar especial na história do cristianismo e nos planos de Deus em relação ao futuro da humanidade. De acordo com Harvey Cox (1995, p. 47):

Os pentecostais creem que, após a manifestação original da descida de fogo do céu [aquela relatada no livro dos Atos dos Apóstolos], algo havia dado errado. Ao invés de anunciar as boas novas a todas as nações, os cristãos se tornaram presunçosos e indolentes. Eles passaram a escrever credos meticulosos e a inventar rituais sem vida. Séculos se passaram e o cristianismo se degenerou, mas Deus não desistiu. Aqui e ali, Ele enviou uma "pitada" de bênçãos, mas prometeu que, antes do clímax da história, Ele as derramaria em torrentes da "última chuva" [latter rain], prevista pelo profeta Joel, que superaria até mesmo o primeiro Pentecostes em potência. Haveria um ressurgimento da fé por todo o mundo e as curas e milagres, que foram tão evidentes nos primeiros anos do cristianismo, aconteceriam novamente como um prelúdio da Segunda Vinda de Jesus Cristo, desta vez para estabelecer o seu reino visível. ${ }^{5}$

Entretanto, a expectativa da iminência do fim, a espontaneidade, o primado da oralidade sobre a tradição teológica e uma certa informalidade que marcou os primórdios do movimento pentecostal foram, aos poucos, tendo

\footnotetext{
${ }^{5}$ Tradução nossa. O mesmo ocorre com as demais citações de textos em inglês que se encontram nas referências bibliográficas.
} 
que conviver com um processo lento e gradual de institucionalização em igrejas locais e denominações de caráter nacional. Novas "revelações do Espírito Santo" levaram a sucessivas cisões dentro dos incipientes grupos pentecostais. Podemos perceber já nos dezessete artigos do primeiro Statement of Fundamental Truths das Assembleias de Deus norte-americanas de 1916 traços da influência da perspectiva teológica conservadora fundamentalista e do literalismo bíblico sobre setores do movimento pentecostal.

Apesar de terem sido alvos constantes de ataques de lideranças fundamentalistas - George Campbell Morgan chegou a chamar o tongues movement de "the last vomit of Satan" -, as igrejas pentecostais que começaram a se organizar nos Estados Unidos na década de 1910 aderiram a vários dos princípios fundamentalistas, e a crença na latter rain foi perdendo espaço para as teorias da escatologia dispensacionalista. As principais lideranças fundamentalistas dos Estados Unidos eram adeptas desse método de interpretar o texto bíblico organizado por John Nelson Darby e popularizado no país através da Bíblia de Estudos Scofield. Segundo os dispensacionalistas, a Bíblia anuncia uma perspectiva de história dividida em sete eras ou "dispensações". C. I. Scofield (1967, p. 5), o principal divulgador das crenças dispensacionalistas nos Estados Unidos no início do século XX, afirmava que "uma dispensação é um período de tempo durante o qual o homem é testado em relação à sua obediência a alguma revelação específica da vontade de Deus". As dispensações, ou as diferentes formas como Deus teria lidado com a humanidade ao longo do tempo, seriam as seguintes: 1) a "Inocência", que terminaria com a Queda e a expulsão de Adão e Eva do Paraíso; 2) a "Consciência", que se findaria com o Dilúvio; 3) "O Governo Humano", que seria encerrado em Babel; 4) a "Promessa", que acabaria na escravidão no Egito; 5) a "Lei", que terminaria com a rejeição e crucificação de Cristo; 6) a "Graça" ou "Período da Igreja", que se encerraria com o governo do Anticristo durante a Tribulação, a Batalha do Armagedom e a Segunda Vinda de Cristo; e, por fim 7) o "Milênio", no qual Cristo reinaria pessoalmente na Terra junto aos seus santos.

No sistema dispensacionalista, não há espaço para alegorias ou sentidos figurados: a não ser que o texto ou contexto indicassem claramente outra coisa, a única maneira adequada de se interpretar as Sagradas Escrituras seria a partir de seu sentido literal (MARSDEN, 2006, p. 60). Dessa forma, por exemplo, várias interpretações de profecias sobre Israel que foram feitas ao longo dos anos por diversos cristãos - como muitos dos puritanos -, que as entendiam como uma referência não ao povo de Israel, mas sim à Igreja (o "novo Israel de Deus") ou aos Estados Unidos, foram rejeitadas. Em seu literalismo, os dispensacionalistas afirmavam que quando a Bíblia fala de Israel ela se refere aos judeus. Essa perspectiva, somada às diversas profecias sobre Israel consideradas como ainda não cumpridas, levou os dispensacionalistas à conclusão de que existem dois "povos de Deus" com os quais Ele lidaria de modo distinto: o Seu "povo terreno" (earthly 
people) - que seria Israel - e o Seu "povo celestial" (heavenly people) - que seria a Igreja.

Ao seu povo terreno, Deus teria se revelado nas primeiras seis dispensações. Durante a quinta dispensação - o período da "Lei" -, há um episódio, relatado em II Samuel 7:8-16, extremamente importante para entender a lógica dispensacionalista, especialmente em relação à questão dos judeus. O sétimo capítulo do segundo livro de Samuel narra um pacto feito entre Deus e o rei Davi, no qual Javé afirma que "quando teus dias forem completos, e vieres a dormir com teus pais, então farei levantar depois de ti um dentre a tua descendência, o qual sairá das tuas entranhas, e estabelecerei o seu reino. Este edificará uma casa ao meu nome, e confirmarei o trono do seu reino para sempre".

A restauração do trono de Davi é uma esperança que aparece nos textos da apocalíptica judaica e entre os profetas. O messias aguardado é visto como o herdeiro da linhagem de Davi que trará um período de paz, justiça e glória para Israel. Em Jeremias (33:15-16), é dito que "naqueles dias e naquele tempo farei brotar a Davi um Renovo de justiça, e ele fará juízo e justiça na terra. Naqueles dias Judá será salvo e Jerusalém habitará seguramente". O Segundo Testamento se inicia, no Evangelho de Mateus, com uma longa genealogia que é chamada de "livro da geração de Jesus Cristo, filho de Davi, filho de Abraão" (Mt 1:1). A afirmação de Jesus como "filho de Davi" significava o cumprimento do pacto entre Deus e Davi na manutenção de sua linhagem real para todo o sempre. O messias deveria reinar no trono de Davi, em Jerusalém. Entretanto, Jesus "veio para o que era seu, e os seus não o receberam" (Jo 1:11). Os judeus teriam rejeitado o pacto da sexta dispensação - período da "graça". Entretanto, no entendimento dos dispensacionalistas, o pacto de Deus com Davi não foi rompido. Scofield $(1967$, p. 362) explicava que "a desobediência na família de Davi seria castigada, mas a aliança entre Deus e a descendência de Davi não seria revogada". O castigo veio com a divisão dos reinos de Judá e Israel, com o cativeiro babilônico, com a destruição do templo de Jerusalém, com a diáspora etc. Mas o pacto feito com Davi seria imutável. Deus ainda haveria de restaurar seu "povo terreno" no fim dos dias. A sexta dispensação tornou-se, com a rejeição de Jesus pelos judeus, o tempo de um "grande parêntese" na relação entre Deus e Israel. É o tempo dos gentios e o tempo da Igreja.

Segundo Timothy Weber (1979, p. 19), na perspectiva dispensacionalista, "quando os judeus rejeitaram a Jesus como seu messias, Cristo adiou seu aguardado retorno e, inesperadamente, voltou sua atenção para os gentios". Seria o período no qual Deus interromperia sua relação com seu "povo terreno" e voltaria sua atenção ao seu "povo celestial", aqueles de fora do "arraial de Israel" que aceitaram o pacto da graça anteriormente rejeitado pelos judeus. Seria, assim, o "grande parênteses" na relação entre Javé e 
Israel que mencionamos anteriormente. Esse seria também um período em relação ao qual as profecias diriam muito pouco: não haveria profecias específicas sobre a Igreja.

As profecias restantes se refeririam à última semana das setenta semanas de Daniel $^{6}$ que ainda aguarda seu cumprimento. Seria um período de sete anos que precederia o Milênio e se iniciaria com o fim da era da Igreja. Mas, mais especificamente, são dois acontecimentos ligados à relação entre Cristo e seu "povo celestial" que delimitam o período dos sete anos: o início com o Arrebatamento dos cristãos e o fim com o retorno destes junto com Jesus na parousia. No Arrebatamento, Cristo viria somente para os seus santos. Na segunda vinda, Cristo viria com os seus santos para derrotar o Anticristo e inaugurar o Milênio. Assim, durante a septuagésima semana, os cristãos não estariam mais na terra e não enfrentariam as perseguições e o período de trevas que marcariam esses 7 anos de Tribulação. Na perspectiva pré-tribulacionista dos dispensacionalistas, a Igreja seria removida para que Deus realizasse sua vontade final para o seu "povo terreno", os judeus. Seria um período de grande perseguição aos judeus e durante esses anos vários deles compreenderiam que Jesus seria, de fato, o messias. De acordo com Boyer (1992, p. 89), "após uma terrível perseguição durante o reinado do Anticristo, um remanescente dos judeus sobreviventes finalmente aceitaria o messias que rejeitara por tanto tempo". De acordo com Timothy Weber (1979, p. 23), ao final desse período de tribulação, o trono de Davi seria restaurado e o Milênio haveria de ser "um reino judeu, completo com um templo restaurado, sacrifícios diários e um poderoso rei Jesus reinando em Jerusalém e exercendo a hegemonia judaica sobre o resto do mundo". Após o reinado de mil anos, Satanás

\footnotetext{
${ }^{6}$ Uma passagem-chave para entender o sistema dispensacionalista é a chamada profecia das 70 semanas de Daniel (Dn 9:22-27). A complexa interpretação feita pelos dispensacionalistas dessa passagem é fundamental para dar sentido a todo o sistema. Seguindo uma linha interpretativa comum a todos os dispensacionalistas, Scofield (1967) afirma que as tais 70 semanas seriam semanas de anos: mais claramente, 70 semanas compostas, cada uma, por sete anos, num período total de 490 anos. As divisões desse período que aparecem no texto seriam assim: 7 semanas (49 anos), 62 semanas (434 anos) e uma semana (7 anos). Os dispensacionalistas argumentam que as 70 semanas teriam tido início em 445 a.C, com a autorização dada por Ataxerxes I a Neemias para que este reconstruísse o templo de Jerusalém - "desde a saída da ordem para restaurar, e para edificar a Jerusalém [...]" Nas primeiras 7 semanas (445 a 396 a.C), "Jerusalém deveria ser reconstruída em meio a tempos turbulentos. Isso foi cumprido de acordo com os registros de Esdras e Neemias" (SCOFIELD, 1967, p. 914). As 62 semanas subsequentes representariam o período que iria até a morte do Messias. Partindo de sua interpretação literalista do texto bíblico que, segundo criam, dizia que entre o período da autorização para a reconstrução do templo e a crucificação de Jesus haveria uma diferença de 483 anos, os dispensacionalistas fizeram uma série de cálculos complexos - que levaram em conta anos bissextos, calendário judaico, diferenças entre o calendário juliano e o ano solar etc. - que, segundo eles, comprovariam sua teoria. Um ponto peculiar da interpretação dispensacionalista dessa profecia é o entendimento de que há um intervalo indeterminado entre o final da sexagésima nona semana e o início da septuagésima (e última) semana.
} 
seria liberto e incitaria nova rebelião que seria rapidamente derrotada. Após isso, viria a ressurreição dos mortos, o julgamento final e o início da eternidade em novos céus e nova terra.

Entre os pentecostais brasileiros, a perspectiva pré-milenarista e dispensacionalista ainda é a narrativa majoritária na área da escatologia. Na seção "Em que cremos" do site oficial do principal dos ramos das Assembleias de Deus (Convenção Geral das Assembleias de Deus do Brasil), vemos a reafirmação das crenças pré-milenaristas e de elementos dispensacionalistas, como o Arrebatamento pré-tribulacional: Crê-se "na segunda vinda de Cristo, em duas fases distintas: a primeira - invisível ao mundo, para arrebatar a sua Igreja antes da Grande Tribulação; a segunda - visível e corporal, com a sua Igreja glorificada, para reinar sobre o mundo durante mil anos". ${ }^{7}$ Livros de autores dispensacionalistas famosos como Hal Lindsey e Tim LaHaye tiveram grande impacto nas interpretações escatológicas dos pentecostais brasileiros nas últimas décadas do século XX, especialmente no contexto da Guerra Fria. As décadas de 1970 e 1980 foram marcadas por um boom de obras dispensacionalistas que se tornaram verdadeiros best sellers e ajudaram a popularizar algumas das crenças dessa perspectiva escatológica. Por exemplo, o livro The Late Great Planet Earth (lançado no Brasil com o título de A agonia do grande planeta Terra) de Hal Lindsey, publicado originalmente em 1970, obteve vendas na casa dos 30 milhões de cópias apenas nos Estados Unidos, tornando-se, segundo Woljcik (1997, p. 37), o livro de não-ficção mais vendido naquele país na década de $1970 .{ }^{8}$ Autores dispensacionalistas norte-americanos - como Lindsey, LaHaye e John F. Walvoord - tiveram seus livros traduzidos para o português e lançados no Brasil por editoras como Mundo Cristão e Editora Vida com pouca diferença de tempo em relação às edições originais.

Importantes estudiosos do pentecostalismo vincularam a apatia política, o sectarismo e o desinteresse por questões sociais dos pentecostais a essa perspectiva escatológica pré-milenarista. Por que se engajar politicamente se não se poderia esperar nada de melhor deste mundo antes da volta de Jesus? Como buscar uma sociedade cristã se as instituições mundanas estavam sob a influência "demoníaca" e todo o planeta seria em breve subjugado por uma liderança política manipulada pelo próprio Satanás? Se a derrota na arena política era inevitável, por que lutar? A luta justificável seria aquela por conquista de almas para Jesus numa batalha contra as tentações do mundo e as forças espirituais satânicas. As armas para tal batalha seriam

\footnotetext{
${ }^{7}$ CONVENÇÃO GERAL DAS ASSEMBLEIAS DE DEUS NO BRASIL. Em que cremos. Disponível em: <https://assembleia.org.br/em-que-cremos/>. Acesso em 15 de jun. 2020.

${ }^{8}$ Analisamos o desenvolvimento do dispensacionalismo nos Estados Unidos e sua popularização no período da Guerra Fria em trabalho anterior: ROCHA, D. Fim dos tempos nos Estados Unidos: escatologia, fundamentalismo religioso e identidade nacional em Hal Lindsey e Tim LaHaye (1970-1980). 2017. Tese (Doutorado em História) - Universidade Federal de Minas Gerais, Belo Horizonte, 2017.
} 
as espirituais, especialmente orações e exorcismos, e a prática de uma vida reta, livre de vícios e de relacionamentos mais profundos com o "mundo". Os problemas sociais e políticos seriam reflexos desta luta, pois aqueles em posição de poder no Brasil estavam do lado do "mal", do lado do catolicismo, da cultura brasileira, das hostes satânicas, da secularização etc.

Entre os pesquisadores brasileiros que se dedicaram ao estudo das práticas sociais e políticas dos pentecostais, o livro O refúgio das massas do suíço Christian Lalive D'Epinay (1970) exerceu um grande impacto. Muitas das percepções desse autor sobre o pentecostalismo chileno foram "transplantadas" para as análises do pentecostalismo brasileiro. Para D’Epinay, uma característica central da visão pentecostal do mundo é a radical separação entre a "vida espiritual" e as "coisas do mundo". A vida cristã deveria ser pautada pela busca da salvação e santificação pessoal. Dessa forma, a religiosidade pentecostal repousaria "sobre a dicotomia do espiritual e do material, da Igreja e do mundo, do espírito e da carne. O Evangelho tem relação apenas com os dois primeiros destes termos e através deste filtro se faz a leitura da Bíblia" (D“EPINAY, 1970, p. 179). Uma das implicações diretas de tal visão de mundo seria a alienação política que caracterizava os pentecostais pesquisados por D'Epinay: "para a maioria deles, a política (tomada em sentido amplo que engloba também o econômico e o social) não tem nada a ver com o Evangelho" (D'EPINAY, 1970, p. 178). Uma das bases teológicas que embasariam tal posicionamento seria a hegemônica perspectiva escatológica pré-milenarista:

O Reino de Deus continua sendo entendido como alguma coisa transcendente, do qual as comunidades são o sinal visível mas sem relação de continuidade com o significado do que indicam. O Reino de Deus virá do céu; é radicalmente diferente e não poderia inscrever-se no prolongamento de uma ação humana. Esta concepção escatológica significa (mais do que determina) a passividade sociopolítica do pentecostalismo (D'EPINAY, 1970, p. 200).

Pesquisadores do pentecostalismo brasileiro chegaram a conclusões semelhantes às de D'Epinay. Segundo Antônio Gouvêa de Mendonça, a escatologia pré-milenarista, conforme forjada no fundamentalismo norte-americano, transplantada para o Brasil não deixou espaços para "teorias que defendiam a ação direta dos indivíduos e da igreja na condução das coisas 'deste mundo', como as teorias imanentistas em geral (...) incorporadas nos conceitos de liberalismo ou modernismo foram rejeitadas e banidas como heréticas". (MENDONÇA, 2004, p. 70-71). O pré-milenarismo seria, na opinião do historiador Paulo Siepierski (2004, p. 81), o "responsável" por uma separação do mundo por parte daqueles que o confessam. "Essa separação revela-se, por exemplo, no desprezo ao prazer, no isolamento cultural, na passividade sociopolítica e no pessimismo em relação a qualquer esforço para transformação da sociedade". Para Saulo Baptista (2009, p. 80), "essa concepção do fim da história explica por que o pentecostal não participa dos movimentos sociais e das ações políticas com o propósito de 
construir uma sociedade melhor". O autor vai mais longe quando afirma que "há uma tendência do pentecostal esperar (desejar) que a situação piore, rapidamente, para que Cristo volte logo".

Nessa perspectiva, a máxima que imperou durante muitos anos nos ambientes pentecostais era que "crente não se envolve com política". Mais do que determinante dessa visão negativa da política, o pessimismo escatológico dos pentecostais era uma expressão de descontentamento de um grupo religioso minoritário, muitas vezes discriminado e composto por fiéis que se encontravam nos estratos economicamente inferiores da sociedade. Os "sinais dos tempos" não indicavam a possibilidade de um período de paz e prosperidade para os pentecostais na terra. Isso só seria viável após a intervenção sobrenatural de Deus na história e a Segunda Vinda de Jesus Cristo.

\section{2 "O Brasil é do Senhor Jesus"}

As crenças escatológicas são ininteligíveis se dissociadas de seu contexto de formação e, nos termos de Koselleck (2006), das experiências e expectativas dos grupos que as confessam. Se os visionários entendem que os relatos sobre o tempo do fim são revelações recebidas de seres celestiais sobre eventos relacionados ao fim da história, nós devemos entender sua formação e suas interpretações como frutos das experiências dos homens no tempo. As esperanças escatológicas devem ser interpretadas na dimensão do "futuro presente", o futuro cuja proximidade ou distância tem sua repercussão no presente na forma de variadas expectativas. E tais expectativas em relação ao futuro, muitas vezes, têm o enorme poder de transformar o presente - e, em não menos vezes, de dar novos significados ao passado. Por outro lado, na dinâmica entre experiência e expectativas de Koselleck, o "passado presente" é o referencial para qualquer expectativa que se tenha em relação ao futuro. Uma nova percepção sobre o presente pode ser responsável por uma transformação em relação ao futuro esperado.

Dessa forma, compreender a passagem do discurso de o "crente não se envolve em política" para o chamado a "ganhar o Brasil para Jesus" passa, obrigatoriamente, por entender uma série de transformações internas e externas ao pentecostalismo que tiveram profunda influência na forma como parte de suas lideranças passaram a pensar seu papel no contexto político e "espiritual" do Brasil. Algumas das características, sociopolíticas e teológicas, que marcavam os pentecostais e o pentecostalismo no Brasil não possuem mais o poder de sintetizar os pensamentos e atitudes desse setor do campo religioso brasileiro. O pentecostalismo torna-se cada vez mais heterogêneo e é necessário entender algumas dessas mudanças para que as falas de Malafaia e seus companheiros se tornem inteligíveis. 
No campo da política, os primeiros passos no sentido de uma nova percepção em relação à participação dos pentecostais na política brasileira se deram durante o período do Regime Militar. Tal como ocorreu entre os setores conservadores das demais igrejas cristãs brasileiras, os pentecostais aderiram ao discurso de que o golpe civil-militar teria sido uma resposta divina às preces e súplicas dos cristãos para que Deus livrasse o Brasil da ameaça do comunismo ateu. Entretanto - apesar de experiências ainda nos anos 1970 de "candidatos oficiais" lançados pela igreja O Brasil Para Cristo -, a entrada efetiva dos pentecostais na política eleitoral brasileira, com a mobilização das lideranças das igrejas no sentido de eleger candidatos ligados às suas denominações, só ganhou forma às vésperas das eleições de 1986, nas quais seriam eleitos os parlamentares que haveriam de participar da confecção da nova Constituição do país. Paul Freston afirma que as lideranças pentecostais passaram a enfatizar a "Assembleia Nacional Constituinte (ANC) como um momento em que seria possível reescrever o Brasil, ou pelo menos impedir que outros o reescrevessem" (FRESTON, 1994, p. 64). Difundiu-se a ideia de que a eleição de "homens de Deus" seria fundamental para impedir a concretização de alguns "fantasmas" que assombravam os pentecostais, como a volta do status de religião oficial do catolicismo, a legalização das drogas e do aborto e a aprovação de leis que ampliassem os direitos dos homossexuais. No livro Irmão vota em irmão: os evangélicos, a Constituinte e a Bíblia, que foi muito influente especialmente entre lideranças da Assembleia de Deus, Josué Sylvestre (1986, p. 29-30) afirmava que:

Será agora, em 1986, ou nunca mais! Ou sacudimos esse opróbrio dos nossos ombros, livrando-nos dessa acomodação, desse desinteresse, dessa falta de coordenação, dessa falta de inteligência, dessa falta de amor, e elegemos parlamentares e administradores evangélicos em todas as eleições que surgirem de agora em diante, ou veremos o nosso país, cada vez mais, sendo arrastado para o lodaçal da corrupção e da má administração. [...] Este é o binômio infalível: Oração e Ação. Não adianta apenas orar pelo Brasil. É preciso lutar por ele com as armas de que dispomos: pacíficas, legais, honradas - as nossas atitudes e, sobretudo o nosso voto.

Igrejas como as Assembleias de Deus, a Igreja do Evangelho Quadrangular e a emergente Igreja Universal do Reino de Deus perceberam o valor e as possibilidades do voto de seus fiéis e se mobilizaram para eleger seus representantes no Congresso Nacional. O modelo de organização eleitoral de 1986 foi bem sucedido e foi sendo aperfeiçoado nas eleições seguintes, com um crescente número de representantes pentecostais sendo eleitos. Apesar de algumas resistências internas ainda existirem nessas igrejas, os resultados práticos mostram que tais resistências não têm sido fortes o suficiente para atrapalhar os projetos de poder das lideranças eclesiásticas e dos parlamentares pentecostais. "A participação na esfera da política se tornou fundamental para esse grupo religioso que, embora em expansão, é minoritário e se sente discriminado na sociedade civil e no sistema político brasileiro" (MACHADO; BURITY, 2014, p. 602). 
Mas não foi somente o sucesso eleitoral que ajudou a transformar a autoconsciência pentecostal no Brasil. É sabido que os pentecostais não são mais uma parcela numericamente insignificante e sem poderio econômico da população brasileira. Os dados dos últimos Censos vêm mostrando um crescimento em ritmo acelerado do número de pentecostais no país. $\mathrm{O}$ Censo de 2010 já apontou que mais de 25 milhões de brasileiros, quando perguntados sobre sua pertença religiosa pelos recenseadores do IBGE, se afirmaram como membros de alguma igreja pentecostal. Além disso, como pôde ser visto no exemplo das Assembleias de Deus, "a partir dos anos 1970, acentuou-se um processo de mobilidade social ascendente no campo pentecostal." (BAPTISTA, 2009, p. 90). O incremento do número de pentecostais de classe média fortaleceu os vínculos destes com o mundo e embalou sonhos de sucesso pessoal, profissional e político intraterrenos. Os "usos e costumes", o sectarismo e a apatia política poderiam ser viáveis para pequenas congregações pentecostais no ambiente de cidades de menor porte. Mas, a partir da expansão numérica e diversificação social do campo pentecostal, tais características passaram a ser questionadas. Tornavam-se impraticáveis para novos pentecostais de uma classe média ascendente que queriam manter sua fé, mas também desejavam melhorar seu nível de vida e, inclusive, influenciar a esfera política para defender seus interesses. Seria ingenuidade não crer que tais transformações tiveram implicações nas expectativas escatológicas dessas pessoas. Podiam até mesmo crer que o retorno de Jesus era iminente, mas também estavam preocupados em "melhorar de vida", em adquirir bens materiais, comprar casas e automóveis utilizando financiamentos de longo prazo, contratar planos de saúde e previdência privada etc.

$\mathrm{Na}$ arena política, a crença de que "crente não se mete em política" foi perdendo espaço para uma convicção cada vez mais consolidada de que o "povo de Deus" precisa influir nos rumos da nação e na construção de um "futuro melhor". Com o passar dos anos, espalhou-se a perspectiva "cada vez mais frequente em reuniões, cultos, programas de rádio e TV, do horizonte de um Brasil politicamente 'evangélico'" (SANCHIS, 1999, p. 214). Enquanto Jesus não volta, caberia à igreja do Senhor "fazer diferença" no mundo. E não mais apenas tentando "ganhar almas para Jesus" ou buscando se santificar afastando-se das concupiscências da carne. Era necessário que os verdadeiros cristãos se inserissem nas esferas de poder para, dali, transformarem a nação. Essa fala de 1992 da conhecida missionária pentecostal Valnice Milhomens dá uma ideia dessa mudança no tom desse "novo chamado" pentecostal:

E, meus irmãos, vocês sabem que a Igreja tem que ocupar os lugares no Brasil? Olha, no ano das eleições do presidente da República, nós estávamos orando em Recife. Íamos orar pelas eleições. Deus me interrompeu no meio da oração: tira os olhos dos candidatos. Levanta os teus olhos para a Igreja, porque a solução dos problemas do Brasil está na Igreja. Aleluia! E desde aquele dia eu estou na ofensiva, preparando a Igreja. E chegou a hora de a Igreja ocupar os 
postos de liderança desta nação. Não é só a igreja lá atrás dos quartos orando não. É a igreja lá nos postos de comando administrando a nação. (...) Eu sonho com gente no Palácio do Planalto que teme a Deus acima de tudo. E que não vai depender da sua esperteza, mas que vai buscar os princípios do reino na Palavra de Deus. É assim que nós vamos erradicar as maldições do país. É na Igreja que está a solução. É na Igreja. Estamos crescendo e vamos explodir, em nome de Jesus. (...) Cada um devia estar votando num crente. Num crente. Começar a invadir. Comece, irmão, já. Comece agora, nas prefeituras, depois para os governos, até chegar à presidência. Vamos tomar conta do Brasil. Ou vocês não creem que a Igreja tem que salgar a massa toda, hem? Fica só na defensiva? Não. A Igreja tem que salgar a massa toda. (MILHOMENS apud ROMEIRO, 1999, p. 162-163).

Essa retórica com certo tom triunfalista também era (e ainda é) inspirada por tendências teológicas e doutrinárias que, vindas dos Estados Unidos, passaram a influenciar as igrejas brasileiras. Autores como Paulo Siepierski (1997) e Ricardo Mariano (2005) argumentam que no ambiente pentecostal brasileiro, a partir do final da década de 1970, começaram a surgir igrejas que, apesar de guardarem vários elementos do pentecostalismo tradicional, apresentavam uma série de inovações litúrgicas, teológicas e organizacionais. É o chamado neopentecostalismo (Mariano) ou pós- pentecostalismo (Siepierski) que tem na Igreja Universal do Reino de Deus seu modelo arquetípico. Aprofundar-nos no estudo do neopentecostalismo não é nosso interesse aqui - e nem seria viável, devido às limitações deste texto. Entretanto, suas duas principais ênfases teológicas têm tido grande impacto na autoconsciência e atuação política dos pentecostais brasileiros: a teologia da prosperidade e a noção de "batalha espiritual". Resumidamente, na teologia da prosperidade - chamada por alguns autores norte-americanos de health and wealth gospel - crê-se no poder dos cristãos de influir na esfera espiritual determinando a realidade material. De acordo com Mariano (2005, p. 152-153), a teologia da prosperidade está ligada à noção de "confissão positiva", que seria a "crença de que os cristãos detêm poder - prometido nas Escrituras e adquirido pelo sacrifício vicário de Jesus - de trazer à existência, para o bem ou para o mal, o que declaram, decretam, confessam ou determinam com a boca em voz alta". Por sua vez, a batalha espiritual, na definição de Siepierski (1997, p. 52-53) parte da concepção de que "como a esfera espiritual controla a realidade material, as mudanças materiais dependem da neutralização dos demônios no campo espiritual. Por isso é que existe a guerra espiritual. É uma luta para libertar as pessoas da opressão causada pelos demônios." (SIEPIERSKI, 1997, p. 53).

Nos Estados Unidos, há uma tradição dentro dos ramos mais conservadores do calvinismo que possui um caráter fortemente pós-milenarista e foi muito crítico do dispensacionalismo e suas consequências sobre a participação dos cristãos na política e na sociedade. Nessa tradição, uma voz que se levantou tanto contra o dispensacionalismo quanto contra a apatia social e 
política foi o teólogo Cornelius Van Til. Sobre Van Til, Klein (2011, p. 149) afirma que a base de seu pensamento repousava sobre a ideia de que "os cristãos não poderiam se resignar a um isolamento em suas casas e suas igrejas - ética, política, arte e educação, tudo deve ser recuperado para Cristo ou abandonado para Satanás". As ideias de Van Til tinham um lugar periférico no universo fundamentalista norte-americano e possuíam poucos adeptos, mesmo entre os setores mais conservadores do presbiterianismo. Um de seus alunos, Rousas J. Rushdoony, foi responsável por difundir essas ideias nos Estados Unidos na segunda metade da década de 1970, dando origem ao movimento chamado Reconstrucionismo. Os reconstrucionistas advogavam a necessidade de se "reconstruir" a sociedade e suas instituições a partir dos padrões bíblicos, em especial das leis veterotestamentárias. De fato, o reconstrucionismo sistematizava uma crença que já caracterizava, pelo menos implicitamente, o fundamentalismo desde seus primeiros passos: a noção de que se pode, caso os ordenamentos divinos e os preceitos bíblicos sejam colocados em prática, construir um modelo de sociedade perfeito na terra. Apesar de a pecaminosidade latente do ser humano ser um empecilho para esse aperfeiçoamento, o estabelecimento de leis biblicamente embasadas para reger o funcionamento da sociedade pode, mesmo que seja numa perspectiva de longo prazo, "educar" gradualmente uma sequência de gerações para que, um dia, estabeleça-se uma sociedade legitimamente cristã e composta por genuínos cristãos. Nessa tradição, destaca-se a noção de "Domínio", ligada à interpretação de que a palavra de Deus para Adão e Eva relatada em Gênesis 1:28 - "Então Deus os abençoou e lhes disse: Frutificai e multiplicai-vos; enchei a terra e sujeitai-a; dominai sobre os peixes do mar, sobre as aves do céu e sobre todos os animais que se arrastam sobre a terra" - era válida para os cristãos de hoje. Eles deveriam ter domínio sobre toda a Terra, seus recursos e suas instituições. Dessa forma, autores reconstrucionistas como David Chilton (1994) falavam de uma Teologia do Domínio.

Apesar de manterem, oficialmente, a crença na narrativa escatológica dispensacionalista, alguns pentecostais simpatizavam com princípios do reconstrucionismo. Se os reconstrucionistas não conseguiram "converter" muitas lideranças à sua escatologia pós-milenarista, várias de suas ideias se popularizaram no ambiente fundamentalista e pentecostal, como o chamado aos cristãos para que se engajem na transformação de todos os aspectos da cultura e a "aplicação da lei bíblica para uma sociedade reconstruída" (INGERSOLL, 2015, p. 209). Especialmente os que se aventuravam no campo da política a partir do fortalecimento da Direita Cristã nos Estados Unidos do início dos anos 1980, como o pentecostal Pat Robertson, incorporaram parte da retórica do "domínio" a seus discursos - sem maiores preocupações em relação às aparentes contradições no terreno das crenças escatológicas. No Brasil, a Teologia do Domínio se consolidou com um viés nitidamente pentecostal e amalgamado com elementos da teologia da prosperidade e da batalha espiritual. A princi- 
pal influência entre lideranças pentecostais brasileiras é a perspectiva de Teologia do Domínio sustentada pelo teólogo e pastor norte-americano C. Peter Wagner. McVicar (2015, p. 200) afirma que a noção de domínio em Wagner combina elementos da ideia de mandato cultural - na tradição de Van Til e Rushdoony - de "cristianizar" todas as áreas da existência e atuação dos homens com noções pentecostais de batalha espiritual. De acordo com Nina Rosas (2015, p. 246), Wagner defende

que o domínio e a autoridade sobre a terra foram dados por Deus aos homens desde Adão, mas foram perdidos pelo pecado original. Recuperados por Jesus através do sacrifício vicário, devem ser retomados pelos crentes. Isso se daria por meio de luta espiritual contra o diabo, que estaria bloqueando a atmosfera da terra e impedindo o fluxo do céu e a emanação de bênçãos advindas do alto. Como corolário, pensa-se que os fiéis não estariam em seus locais de trabalho apenas para sobreviver. Teriam a oportunidade de exercer liderança, dominar e ditar regras de acordo com os valores do reino de Deus.

No Brasil - e as falas dos líderes reunidos com Bolsonaro refletem essa percepção - a Teologia do Domínio se funde com a teologia da prosperidade nas declarações de que "o Brasil é do Senhor Jesus" e, como dito por Malafaia, com o ato de "determinar" que virão tempos de paz e prosperidade, que o povo de Deus desfrutará do melhor desta terra. Por outro lado, a Teologia do Domínio se funde com a teologia da batalha espiritual. Wagner $(2009$, p. 88) fala da existência de seres sobrenaturais (principados e potestades demoníacas) que possuem domínio sobre certos espaços territoriais e culturais. É necessário que o poder de tais seres demoníacos seja quebrado para que a bênção do Senhor seja liberada. Wagner (2009, p. 137) cita em seu livro o exemplo de um missionário sueco (Kjell Sjoberg) que atuou no Brasil e teve contato com alguns "demônios territoriais". Em Manaus, ao tomar consciência dos sérios problemas ambientais pelos quais passa a região, o missionário buscou, através da oração, uma revelação de Deus sobre as potestades que exerciam poder na região. Ao visitar a Opera House em Manaus (provavelmente ele se refere ao Teatro Amazonas), o missionário encontrou um grande mural com uma pintura da Iara. Segundo Wagner, o teatro "foi construído como um templo para a deusa Iara". Quando o missionário "expôs Iara como a chefe do principado da região, o pastor que era seu anfitrião afirmou que, antes de se tornar cristão, era um adorador de Iara. Eles oraram juntos para que o poder de Iara fosse quebrado e a floresta amazônica pudesse ser sarada". Também Brasília, centro do poder político do país, precisaria de libertação de entidades demoníacas. No relato de Wagner (2009, p. 165), baseado na experiência de Sjoberg, há uma curiosa teoria sobre a "inspiração espiritual" por trás da construção da cidade:

Brasília, a capital do país, foi projetada e construída em 1960 pelo presidente Juscelino Kubitschek. Sjoberg relata que Kubitschek era um espírita que acreditava na reencarnação e que pensava ser a reencarnação do faraó Akhnaton, que viveu 3.300 anos atrás e construiu uma nova capital para sua nação. Muitas 
construções têm a forma de pirâmides ou templos egípcios. Os edifícios que abrigam os centros de poder estão localizados em triângulos, formando um hexagrama. A numerologia do tarô egípcio e da cabala hebraica é proeminente em toda parte. A forma da cidade é a de um pássaro íbis egípcio (apesar de alguns guias turísticos apresentarem-na como o formato de um avião). Esse tipo de informação, que revela as forças espirituais enviadas desde a concepção da cidade, torna-se extremamente útil para os intercessores que participam do esforço de oração pela cidade.

\section{Arautos de um novo tempo}

Mesmo com a popularização entre os pentecostais de crenças ligadas, direta ou indiretamente, a uma perspectiva escatológica pós-milenarista, as igrejas pentecostais brasileiras continuaram confessando, com pouquíssimas exceções, uma narrativa escatológica pré-milenarista e dispensacionalista. Podemos afirmar que as transformações estão ocorrendo mais no nível prático do que no teológico. Se, por um lado, não houve uma adesão "oficial" ao pós-milenarismo que tenha precedido a mudança da relação dos pentecostais com a política, por outro lado, apesar de continuarem crendo que o advento do Milênio só ocorrerá após a parousia, o pré-milenarismo não tem fomentado a alienação política e o afastamento do "mundo" que a literatura especializada considerava como consequência lógica de tal crença.

Uma hipótese que podemos levantar, com alguma segurança, é a de que o pessimismo pentecostal - em sintonia com sua crença pré-milenarista/ dispensacionalista - tinha como uma de suas principais razões a consciência de que o poder político e/ou a hegemonia cultural estariam distantes deles e, baseado em seu antagonismo visceral, em poder de "forças malignas". O questionamento de tal poder "diabólico" era feito baseando-se em uma forma antagônica de política e de governo. Uma forma que expressaria os valores divinos, um modelo de reino milenar legitimamente cristão. Sendo a possibilidade da implementação de tal reino algo muito distante e impalpável, tendia-se ao pessimismo e à ansiedade para que essa nova era fosse implantada através de uma interferência divina, dando fim à história e aos governos iníquos. Por outro lado, quando há uma virada nesse quadro - como tem ocorrido nas últimas décadas - e grupos que se consideravam marginalizados começam a acreditar na possibilidade de influir de maneira decisiva nos rumos da nação e a se identificarem como parte da "maioria cristã e conservadora" da população, o pessimismo cede espaço para um discurso que alimenta expectativas intra-históricas de resgate do sonho da "nação cristã".

Como observado por Burity e Machado, os pentecostais no Brasil contemporâneo têm se equilibrado em uma linha tênue entre o discurso que legitima a participação política como forma de sobrevivência frente aos 
"inimigos" externos e outro discurso que fala do papel de ser "sal da terra" no Brasil, numa luta pela narrativa hegemônica da "nação cristã". O primeiro discurso trata "de resistir ao assédio dos movimentos sociais, à discriminação pela mídia, à continuidade dos privilégios desfrutados pela Igreja Católica etc". Já no discurso da luta pela hegemonia cultural, fala-se da "tentativa de permear 'a política' ou 'a sociedade' com os 'valores do Reino de Deus'” (MACHADO; BURITY, 2014, p. 614).

Da mesma forma, no terreno das crenças escatológicas, apesar do crescimento da "influência prática" cada vez maior da Teologia do Domínio, elementos da tradição dispensacionalista ainda aparecem em meio à retórica pentecostal como a crença em grandes conspirações (comunistas, esotéricas, maçônicas); a interpretação literalista e descontextualizada de passagens bíblicas a partir das "lentes" da geopolítica contemporânea; a centralidade do papel de Israel no script do fim dos tempos; e a reafirmação de que, como aparecia em adesivos que circularam em muitos veículos de pentecostais, "em caso de Arrebatamento, esse veículo ficará desgovernado". Nos eventos religiosos e políticos nos quais existe a participação de pentecostais, é muito comum a presença de bandeiras de Israel e, como tem ganhado destaque recentemente, a presença das bandeiras do Brasil, Estados Unidos e Israel juntas (seriam os três "povos eleitos" de Deus?).

Aqui vemos outra incorporação de tendências do fundamentalismo e do pentecostalismo norte-americanos. Com o processo de politização do fundamentalismo nos Estados Unidos na década de 1970, uma das principais ênfases dos dispensacionalistas tornou-se um item fundamental entre as bandeiras da Direita Cristã: a importância da manutenção da aliança entre Estados Unidos e Israel. À importância do retorno dos judeus à "terra prometida" e da evangelização dos "descendentes de Abraão", somou-se uma defesa aguerrida da necessidade do suporte político e militar ao Estado de Israel. O autor dispensacionalista Hal Lindsey (1981, p. 158) dizia que: "Acredito que se os Estados Unidos voltarem as costas a Israel, não mais subsistiremos como nação". Em sua obra On the Road to Armaggedon: How Evangelicals Became Israel's Best Friend - que trata da análise dos discursos e das ações pró-Israel de fundamentalistas norte-americanos inspirados, especialmente, por motivações escatológicas -, Timothy Weber (2004, p. 18) afirma que "começando na década de 1970, eles [dispensacionalistas] viajaram para Israel em grande número e, então, fundaram dezenas de grupos nos Estados Unidos para fazer lobby pró-Israel no Congresso, no Departamento de Estado e nos meios de comunicação". Várias excursões à "Terra Santa" eram organizadas por grupos dispensacionalistas que queriam ver in loco os locais onde haveriam de se cumprir as profecias bíblicas sobre o fim dos tempos. No caso brasileiro, tais tendência foram replicadas e há hoje um forte lobby pró-Israel entre as pautas dos pentecostais na política. $\mathrm{O}$ apoio a Israel seria fundamental tanto para o desenrolar da trama escatológica quanto para os planos de Deus para o 
Brasil. Ao apoiar o "povo terreno" de Deus, os brasileiros se apropriariam da promessa feita por Deus a Abraão em Gênesis 12:3: "abençoarei os que te abençoarem e amaldiçoarei os que te amaldiçoarem".

Com a popularização da Teologia do Domínio entre as lideranças pentecostais brasileiras, algumas frases de efeito e trechos bíblicos como "O Brasil é do Senhor Jesus", "Feliz a nação cujo Deus é o Senhor", "Vamos ganhar o Brasil para Jesus" tornaram-se indicativos não só do crescimento do número de evangélicos no país, mas também da iminência do advento de uma transformação política, social e espiritual do país. Os pentecostais seriam não só arautos como também artífices de um novo tempo. Crendo-se como portadores de revelações e profecias celestiais em relação ao país, lideranças pentecostais têm procurado, através de orações, jejuns, intercessões, atos proféticos e, também, de ações práticas no campo da política (lobbies, alianças, negociações, ocupação de cargos), preparar o país para o advento dessa nova era. Descortina-se, nessa perspectiva, o papel messiânico do "povo de Deus". Sobre os movimentos messiânicos, Maria Isaura Queiroz (1976, p. 29) afirma que:

A transformação não se operará mecanicamente, pela mera aparição do líder; é preciso que os adeptos lhe cumpram as ordens. Destes é a responsabilidade pelas condições da sociedade, seu papel é se voltar para a coletividade, moralizando-a e santificando-a, a fim de permitir o Advento. O messianismo se afirma, pois, como uma força prática, e não como uma crença passiva e inerte de resignação e conformismo: diante do espetáculo das injustiças, o dever do homem é trabalhar para saná-las, pois sua é a responsabilidade pelas condições do mundo. E desde que a crença se ativa, dá então lugar ao movimento messiânico, que se destina a consertar aquilo que de errado existe. Estes objetivos, que são políticos, sociais, econômicos (conforme se localizem os erros neste ou naquele setor), devem sempre ser, no entanto, religiosamente alcançados, isto é, por meio de rituais especiais que um enviado divino revela aos homens.

Nesse sentido, entendemos que é possível, de fato, falar em uma dimensão messiânica nos discursos e práticas de lideranças pentecostais no Brasil contemporâneo. No seu encontro com Bolsonaro, os pastores presentes se apresentavam como representantes do povo escolhido para transformar o Brasil. O pastor Vítor Hugo afirmou no encontro: "Estamos aqui para ser uma voz profética na nação". O poder de oração, intercessão e "amarração" do poder de principados e potestades demoníacas soma-se ao engajamento político eleitoral e ao poder midiático e financeiro das igrejas pentecostais como instrumentos de transformação do Brasil.

Mas seriam os pentecostais o povo messiânico ou, como vários discursos feitos durante aquele ato podem dar a entender, eles estariam ali endossando o papel messiânico que estaria sendo desempenhado pelo presidente Jair Messias Bolsonaro? De fato, em meio a um momento de tensão e certa fragilidade política, aquelas lideranças religiosas se posicionaram claramente em favor do presidente e reafirmaram os desígnios divinos e a vontade 
popular que o colocou no mais alto cargo político da nação. R.R. Soares afirmou que "o Senhor colocou o presidente Bolsonaro para ser o nosso pastor aqui durante 4 anos. [...] Aqueles que são contra o país, ó Deus, que respeitem a decisão do povo. [...] Amarramos todas as forças espirituais contrárias à tua vontade". O Apóstolo Estevam Hernandes ressaltou as "virtudes cristãs" de Bolsonaro: "A Palavra de Deus, ela fala que as autoridades são constituídas por Deus. E nós temos o privilégio de ter na presidência da República um homem que é temente a Deus, um homem que é pela família e que tem valores e princípios que são cristãos. Isso pra nós é resposta de oração". Evocando a figura de Ciro, conforme Isaías 45, o Apóstolo César Augusto (Igreja Fonte da Vida) disse a Bolsonaro:

Deus me deu um texto, presidente, Isaías 45 que fala do Rei Ciro. Deus usou o rei Ciro para libertar os judeus da Babilônia e deu uma ordem pra eles: vá, reconstrua o templo. O templo, para os judeus, era onde Deus estava, era onde os valores de Deus deviam estar. E Deus me deu uma palavra que o senhor recebeu a unção de Ciro pra que o senhor pudesse trazer novamente os valores da Palavra de Deus, que são os valores conservadores, que possam nortear o futuro da nossa nação. E a Palavra do Senhor, eu quero ler esse texto, Isaías diz assim "Assim diz o Senhor ao seu ungido Ciro, cuja mão direita eu seguro com firmeza, para subjugar as nações diante dele, arrancar as armaduras dos reis, para abrir portas diante dele de modo que as portas não estejam trancadas". Deus deu uma unção pro senhor e eu creio que essas portas que estão fechadas essa semana serão abertas. Deus nos trouxe aqui pra declarar que portas trancadas serão abertas. E ele continua dizendo: "Eu irei adiante de você, aplanarei os montes, derrubarei as portas de bronze e romperei as trancas de ferro". Esta semana Deus vai fazer algo tremendo. Nós não estamos aqui a toa. Nós somos voz profética de Deus. A unção do Espírito está sobre ti, presidente. $\mathrm{E}$ todos aqueles que fecharem as portas... Estamos aqui pacificamente, mas somos profetas do Senhor... Deus vai tirá-los do seu caminho.

Ciro foi um rei estrangeiro que foi usado por Deus para libertar Israel. Embora também seja considerado uma figura messiânica, Ciro não é Davi (o homem segundo o coração de Deus). A partir da fala de César Augusto, podemos falar de um encontro entre a retórica messiânica e um certo pragmatismo político. Apesar do bom relacionamento com os evangélicos, de ter recebido um segundo batismo nas águas do rio Jordão - em ato dirigido pelo Pastor Everaldo Dias Pereira - e do fato de sua esposa ser evangélica, Bolsonaro sempre se declarou católico. Bolsonaro passa longe de um certo estereótipo do pentecostal que não consome bebidas alcoólicas e não "fala palavrão". Mas aqui, mesmo sendo esse "rei estrangeiro" no arraial do Senhor, ele é um aliado extremamente importante e estratégico para os pentecostais. Exalta-se o fato de ele ser um "homem temente a Deus" e "defensor dos valores da família" e faz-se certa "vista grossa" ao seu comportamento heterodoxo tendo como parâmetro o forte moralismo que caracteriza os pentecostais.

O que, de fato, nos chama a atenção no contexto e nas falas dos líderes religiosos presentes naquele ato é a retórica em torno do papel de protago- 
nista que os "verdadeiros cristãos" teriam na transformação do Brasil em uma nação feliz que tem Deus por Senhor. Aquele seria um momento de "virada" na história do país. É recorrente em eventos organizados por lideranças influenciadas pelas perspectivas da Teologia do Domínio e da batalha espiritual as orações pela libertação espiritual de cidades e, nesse caso, de países. É comum a expressão "tomar posse em nome de Jesus" de uma determinada região. Na presença de Bolsonaro, Estevam Hernandes deixa clara a influência dessas crenças ao afirmar o "nosso compromisso de orarmos e clamarmos e declararmos que Jesus Cristo é Senhor desta nação". Nesses atos, "em tese, dá-se início a uma nova fase espiritual na cidade e/ou no estado. [...] Essas reuniões começam os chamados 'atos proféticos', isto é, representações feitas no mundo físico que teriam impacto direto no 'mundo espiritual"' (ROSAS, 2015, p. 241).

O último ponto que gostaríamos de ressaltar é a substituição, na retórica desses líderes pentecostais, de um discurso sectário por outro no qual eles se identificam como representantes de valores da maioria do povo brasileiro. Como dito anteriormente, o crescimento numérico, a ascensão social e a conquista de espaços nas esferas de poder têm tornado os pentecostais brasileiros cada vez menos "peregrinos" em uma terra estranha. Ganhou espaço a afirmação de serem representantes da "maioria silenciosa" - discurso que guarda muitas semelhanças com o da Direita Cristã norte-americana ${ }^{9}$-, uma maioria de brasileiros cristãos e conservadores. "A política pentecostal, nesse sentido, não tem um 'projeto' de conquista do Estado e sim articula uma aspiração de hegemonia como busca de permear espaços" (MACHADO; BURITY, 2014, p. 616). Em sua luta pela hegemonia cultural e com a ascensão de um eleitorado e políticos conservadores, os pentecostais têm se sentido cada vez mais "em casa" no Brasil contemporâneo. Eles fazem parte do que entendem como "povo brasileiro", um povo que, segundo afirmou Malafaia no encontro com o presidente, "é um povo pacífico. O povo brasileiro não é povo de quebra-quebra nem de baderna. [...] É o povo do verde e amarelo".

\section{Conclusão}

Maria Isaura Queiroz (1976, p. 31) afirmava que os messianismos "são movimentos em que devemos sempre encontrar, estreitamente unidos, aspectos terrestres e celestes, seja na motivação que os causa, seja nos fins que se propõem, seja nos meios de que lançam mão para atingir a

\footnotetext{
${ }^{9}$ Desenvolvemos uma reflexão sobre o desenvolvimento da Direita Cristã nos Estados Unidos dos anos 1970 em trabalho recente: ROCHA, D. Da "minoria silenciosa" à Maioria Moral: transformações nas relações entre religião e política no fundamentalismo norte-americano na década de 1970. Religião \& Sociedade, Rio de Janeiro, v. 40, n. 1, p. 91-113, 2020.
} 
estes". Procuramos, ao longo deste texto discutir aspectos das crenças escatológicas dos pentecostais brasileiros e como, nos últimos anos, a postura apática de "fuga do mundo" transformou-se em um claro engajamento político e espiritual no sentido de "tomar posse" das bênçãos de Deus e das instâncias de poder no país. O desfrute do reino de Deus, antes pensado como possível apenas após a intervenção sobrenatural de Cristo após a sua Segunda Vinda, já pode começar a ser experimentado aqui. O bispo J. B. Carvalho afirmou durante o encontro que examinamos neste texto que: "Neste momento tão histórico, Senhor, nesse ato profético, onde autoridades se prostram diante de ti, vem e governa, venha o teu governo, faça-se na terra um pedaço do céu". Também chama a atenção a importância dada ao futuro da nação e como o "povo de Deus" - agindo politicamente e espiritualmente - é uma "ferramenta" fundamental para um futuro próspero e pacífico para o país. O Apóstolo Rina falou dessa crença "nas promessas de Deus para a nossa nação. Crendo em tudo aquilo que foi liberado para o nosso destino. Sabendo que o Brasil foi separado para ser um celeiro para as nações e nosso objetivo aqui é cumprir este propósito". O papel messiânico a ser desempenhado pelos pentecostais seria baseado em oração e ação ou, arriscaríamos dizer, em fé e política.

Chegando ao final deste texto, o leitor pode se questionar se não seria ingenuidade discutir crenças e valores legitimadores da ação dos pentecostais no campo político quando os interesses pragmáticos parecem tão evidentes. ${ }^{10}$ De fato, e procuramos deixar claro esse ponto ao longo do texto, a participação dos pentecostais na política brasileira tem uma dimensão pragmática evidente e, muitas vezes, claramente apresentada aos fiéis. Os candidatos indicados pelas igrejas devem ser representantes dos interesses (sejam esses políticos ou pecuniários) das instituições religiosas junto às esferas de poder político. Mas tais motivos seriam suficientes para legitimar frente aos fiéis a intervenção das igrejas no espaço público? Cremos que não.

Em movimentos políticos nos quais há a presença de crenças e símbolos religiosos não se pode negar a importância do imaginário, das crenças, dos valores, dos mitos, das tradições etc. Não podem ser analisados

\footnotetext{
${ }^{10}$ De acordo com reportagem dos jornalistas Bruno Fonseca e Mariama Correia publicada no site Agência Pública em 15 de junho de 2020, parte das igrejas dos pastores que participaram do encontro com Bolsonaro em 05 de junho de 2020 foram "abençoadas" com verbas públicas posteriormente. Segundo a reportagem: "Mais de R\$30 milhões - esse é o valor que a Secretaria de Comunicação da Presidência (Secom) gastou em campanhas veiculadas em rádios e TVs de líderes religiosos que apoiam Jair Bolsonaro. Segundo levantamento da Agência Pública, o governo pagou com verba pública ações publicitárias em cinco veículos ligados a pastores de igrejas evangélicas que se reuniram com o presidente no início de junho, em Brasília. Na ocasião, os líderes se encontraram com Bolsonaro para 'interceder pela nação e levantar um clamor pelo Brasil', como afirmou Silas Malafaia, um dos organizadores do encontro". Referência: FONSECA, B.; CORREIA, M. Governo gastou mais de R\$ 30 milhões em rádios e TVs de pastores que apoiam Bolsonaro. Agência Pública - Agência de jornalismo investigativo. Disponível em: <https://apublica.org/2020/06/governo-gastou-r-30-milhoes-em-radios-e-tvs-de-pastores-que-apoiam-bolsonaro/>. Acesso em: 19 de jun. de 2020.
} 
levando-se em conta apenas os "cálculos racionais". Também é preciso apontar as peculiaridades das motivações religiosas que não podem ser pensadas apenas como "reflexos superestruturais" de interesses econômicos, classistas ou político-partidários. Analisar as relações que os grupos religiosos estabelecem com as questões políticas levando em conta apenas os interesses pragmáticos, não se aprofundando nas implicações das crenças propriamente religiosas em sua atuação, pode levar os pesquisadores a resultados insatisfatórios que colocam o foco em apenas uma camada da questão (muitas vezes, a menos relevante). O próprio estudo de movimentos populares messiânico-milenaristas, inclusive na historiografia e nas ciências sociais brasileiras, se caracterizou, ao longo do tempo, por pesquisas focadas em questões sociais, quando não em termos de luta de classes, "sem, contudo, considerar a importância da religião, dos símbolos, mitos e ritos para a consecução do imaginário dessas comunidades em tais eventos" (GOMES, 2008, p. 16).

Assim como o pentecostalismo, as crenças messiânicas/milenaristas são um tema extremamente instigante e que se constituem em temática profundamente rica e promissora para os pesquisadores que se aventuram nas discussões das relações entre crenças religiosas e política. Mas é necessário que duas observações sejam levadas em conta. 1) Uma premissa essencial - embora, até certo ponto, óbvia - deve ser colocada: as diferentes interpretações do Messias e do Milênio, em suas variadas ênfases, precisam ser compreendidas como construções históricas e não podem ser devidamente entendidas se forem isoladas de seu contexto político, social, econômico etc. É necessário que as diferentes concepções das "últimas coisas" sejam entendidas como elaborações humanas, frutos do encontro dos mitos escatológicos com as esperanças e aspirações das pessoas e grupos ao longo da história. Tanto os textos escatológicos quanto as interpretações e reinterpretações que eles recebem ao longo da história nos mostram muito mais do que uma forma de narrativa mítica desvinculada da realidade: eles podem nos revelar muito sobre as tensões e peculiaridades do seu contexto histórico-político e as interrogações e expectativas quanto ao futuro do grupo que os produz e/ou os interpreta. 2) Por outro lado, como apontamos anteriormente, apesar dessa necessidade de não se "descolar" tais crenças de seu contexto histórico, como se dele elas fossem independentes, também não podemos cair em um reducionismo que as vê apenas como narrativas com fins totalmente pragmáticos, utilizadas para a manipulação de determinados grupos. É necessário compreender o sentido que as questões políticas e sociais têm sob o ponto de vista da fé. Não importa tratar aqui da veracidade de suas premissas. Cumpre-nos constatar que ela é real para aquele que a toma como realidade sagrada. Nesse sentido, o anseio por salvação - salvação essa que pode ter sentidos variados - é a grande "bússola" que ordena os movimentos dos agentes religiosos no terreno da política. 


\section{Referências}

BAPTISTA, S. T. C. Pentecostais e neopentecostais na política brasileira: um estudo sobre cultura política, Estado e atores coletivos religiosos no Brasil. São Paulo: Annablume; São Bernardo do Campo: Instituto Metodista Izabela Hendrix, 2009.

BOYER, P. S. When time shall be no more: prophecy belief in modern American culture. Cambridge: Harvard University Press, 1992.

CHILTON, D. Paradise restored: a biblical theology of dominion. Tyler: Dominion Press, 1994.

CONVENÇÃO GERAL DAS ASSEMBLEIAS DE DEUS NO BRASIL. Em que cremos. Disponível em: <https://assembleia.org.br/em-que-cremos/>. Acesso em 15 de jun. 2020.

COX, H. Fire from heaven: the rise of pentecostal spirituality and the reshaping of religion in the twenty-first century. Cambridge: Da Capo Press, 1995.

D`EPINAY, C. L. O refúgio das massas: estudo sociológico do protestantismo chileno. Rio de Janeiro: Paz e Terra, 1970.

DESROCHE, H. Sociologia da esperança. São Paulo: Paulinas, 1985.

FONSECA, B.; CORREIA, M. Governo gastou mais de $R \$ 30$ milhões em rádios e TVs de pastores que apoiam Bolsonaro. Agência Pública - Agência de jornalismo investigativo. Disponível em: <https://apublica.org/2020/06/governo-gastou-r-30-milhoes-em-radios-e-tvs-de-pastores-que-apoiam-bolsonaro/>. Acesso em: 19 de jun. de 2020.

FRESTON, P. Evangélicos na politica brasileira: história ambígua e desafio ético. Curitiba: Encontrão, 1994.

GOMES, A. M. A. O messianismo milenarista no Brasil e o mito do eterno retorno: limites e possibilidades de reflexão. Ciências da Religião - história e sociedade, São Paulo, v. 6, n. 2, p. 13-35, 2008.

INGERSOLL, J. J. Building God's Kingdom: inside the world of Christian Reconstruction. New York: Oxford University Press, 2015.

KLEIN, K. L. From history to theory. Berkeley: University of California Press, 2011.

KOSELLECK, R. Futuro passado: contribuição à semântica dos tempos históricos. Rio de Janeiro: Contraponto; Ed. PUC-Rio, 2006.

LINDSEY, H. The 1980's: countdown to Armageddon. Nova York: Bantam Books, 1981.

MACHADO, M. D. C.; BURITY, J. A ascensão política dos pentecostais no Brasil na avaliação de líderes religiosos. Dados - Revista de Ciências Sociais, Rio de Janeiro, v. 57, n. 3, p. 601-631, 2014.

MALAFAIA, S. [Ao vivo] - Oração em favor do Brasil com a presença do Presidente Bolsonaro e líderes evangélicos. Silas Malafaia Oficial (Youtube). Disponível em: $<$ https://www.youtube.com/watch?v=Fhn9-bLRxi0>. Acesso em: 15 jun. 2020.

MARDSEN, G. M. Fundamentalism and American Culture. 2nd ed. New York: Oxford University Press, 2006. 
MARIANO, R. Neopentecostais: sociologia do novo pentecostalismo brasileiro. 2.ed. São Paulo: Loyola, 2005.

MCVICAR, M. J. Christian Reconstruction: R. J. Rushdoony and the American conservatism. Chapel Hill: The University of North Carolina Press, 2015.

MELVILLE, H. White jacket. London: The Floating Press, 2011.

MENDONÇA, A. G. Protestantismo brasileiro, uma breve interpretação histórica. In: SOUZA, B. M.; MARTINO, L. M. S. (Orgs.). Sociologia da religião e mudança social: católicos, protestantes e novos movimentos religiosos no Brasil. São Paulo: Paulus, 2004. p. 49-79.

MOLTMANN, Jürgen. A vinda de Deus: escatologia cristã. São Leopoldo: Unisinos, 2003.

NEGRÃO, L. N. N. Revisitando o messianismo no Brasil e profetizando o seu futuro. Revista Brasileira de Ciências Sociais, v. 16, n. 46, p. 119-129, 2001.

QUEIROZ, M. I. P. O messianismo no Brasil e no mundo. 2.ed. São Paulo: Alfa-Omega, 1976.

QUEIROZ, M. I. P. Sebastião no Brasil - o imaginário em movimentos messiânicos nacionais. Revista USP, São Paulo, n. 20, p. 28-41, 1994.

ROCHA, D. Fim dos tempos nos Estados Unidos: escatologia, fundamentalismo religioso e identidade nacional em Hal Lindsey e Tim LaHaye (1970-1980). 2017. 402 p. Tese (Doutorado em História) - Universidade Federal de Minas Gerais, Belo Horizonte, 2017.

ROCHA, D. Da "minoria silenciosa" à Maioria Moral: transformações nas relações entre religião e política no fundamentalismo norte-americano na década de 1970. Religião \& Sociedade, Rio de Janeiro, v. 40, n. 1, p. 91-113, 2020.

ROMEIRO, P. Evangélicos em crise: decadência doutrinária na igreja brasileira. São Paulo: Mundo Cristão, 1999.

ROSAS, N. Dominação evangélica no Brasil: o caso do grupo musical Diante do Trono. Contemporânea - Revista de Sociologia da UFSCAR, São Carlos, v. 5, n. 1, p. 235-258, 2015.

SANCHIS, P. A religião dos brasileiros. Teoria e sociedade, Belo Horizonte, v. 4, p. 213-245, out. 1999.

SCOFIELD, C. I. (Ed.). The Scofield Reference Bible. New York: Oxford University Press, 1967.

SIEPIERSKI, P. Pós-pentecostalismo e política no Brasil. Estudos Teológicos, São Leopoldo, v. 37, n. 1, 1997, p. 47-61.

SIEPIERSKI, P. Contribuições para uma tipologia do pentecostalismo brasileiro. In: GUERRIERO, Silas (Org.). O Estudo das Religiões: Desafios contemporâneos. 2a ed. São Paulo: Paulinas, 2004. p. 71-88.

SYLVESTRE, J. Irmão vota em irmão: os evangélicos, a constituinte e a Bíblia. Brasília: Pergaminho, 1986. 
WAGNER, C. P. Warfare prayer: what the Bible Says about Spiritual Warfare. Shippensburg: Destiny Image, 2009.

WEBER, T. Living in the shadow of the Second Coming: American Premillennialism. New York: Oxford University Press, 1979.

WEBER, T. On the Road to Armaggedon: How Evangelicals Became Israel's Best Friend. Baker Academic, 2004.

WOLJCIK, Daniel. The end of the world as we know it: Faith, Fatalism and Apocalypse in America. New York: New York University Press, 1997.

Artigo submetido em 20.06.2020 e aprovado em 04.12.2020.

Daniel Rocha é Doutor em História pela Universidade Federal de Minas Gerais (UFMG). Bolsista do Programa Nacional de Pós-Doutorado (PNPD) da Capes e professor colaborador no Programa de Pós-Graduação em Ciências da Religião da Pontifícia Universidade Católica de Minas Gerais. Professor de História do Cristianismo no Instituto Santo Tomás de Aquino. Orcid.org/0000-0001-6813-2024. E-mail: danielrochabh@yahoo.com.br

Endereço: Rua Gávea no 74 ap. 1102

Jardim América

30421-340 Belo Horizonte - MG 